Piotr LizAK

Uniwersytet Pedagogiczny, Kraków

\title{
Proces ksztaltowania się słowackiego przemysłu motoryzacyjnego jako wyraz konkurencyjności regionu
}

W warunkach nasilających się procesów globalizacji gospodarki światowej ważną rolę w gospodarce odgrywają wiodące korporacje, które poprzez różnorodne systemy sieciowych powiązań przestrzenno-produkcyjnych organizują światową przestrzeń gospodarczą zgodnie ze swoimi regułami rozwoju. Przejawia się to w działaniach w określonych kierunkach i nasileniu powiązań w zakresie zaopatrzenia surowcowego, dostaw kooperacyjnych, rynków zbytu, przepływów technologii, kapitału oraz decyzji. Działania te prowadzą do utrwalania i pogłębiania istniejących rynków oraz utrwalania lokalizacji działalności poszczególnych oddziałów, a także poszukiwania nowych miejsc lokalizacji i nowych rynków zaopatrzenia oraz zbytu gotowych produktów (Zioło 2006).

Należy zatem przyjąć, że podstawowym celem działalności korporacji międzynarodowych na świecie jest podnoszenie konkurencyjności własnych produktów, zwiększanie efektywności działalności, pogłębianie istniejących, a także opanowywanie nowych rynków, co prowadzi do maksymalizacji zysku wypracowanego przez przedsiębiorstwo. Osiaga się to w znacznym stopniu poprzez nowe lokalizacje w konkurencyjnych regionach i krajach. Oznacza to także, że rozwój społeczno-gospodarczy związanych z nimi struktur regionalnych czy krajowych jest skutkiem rozwoju działalności korporacji w określonym miejscu przestrzeni społeczno-gospodarczej i kulturowej (Zioło 2009).

Zróżnicowana przestrzeń geograficzna, przejawiająca się w określonym poziomie rozwoju społeczno-gospodarczego różnej skali układów przestrzennych (od skali globalnej po skalę lokalna), sprawia, że układy te stwarzają często odmienne uwarunkowania dla nowych impulsów rozwojowych związanych z fazą rozwoju informacyjnego na ich obszarze (Kukliński 2001; Wierzbicki 1995; Zioło 2001; 2003; 2004) Światowe korporacje poszukują nowych miejsc efektywnej lokalizacji i często w zasadniczym stopniu dyktują warunki funkcjonowania swoich firm na terenie poszczególnych krajów i regionów. Dlatego to nie korporacje, ale różnej skali układy przestrzenne poprzez podnoszenie swojej atrakcyjności dla nowych lokalizacji działalności gospodarczej starają się stworzyć jak najkorzystniejsze warunki dla przyciagania na swój teren nowych form działalności gospodarczej, a także zmierzają do pobudzania wewnętrznych czynników rozwojowych (Zioło 2009).

W nawiązaniu do powyższych przesłanek w artykule zostanie omówiony napływ bezpośrednich inwestycji zagranicznych (BIZ) do słowackiego przemysłu motoryzacyjnego oraz wskazane kluczowe czynniki konkurencyjności determinujące ten proces. 
Celem niniejszej pracy będzie więc wskazanie i określenie czynników, które w zdecydowany sposób wpłynęły na lokalizację nowych zakładów produkujących samochody osobowe na Słowacji w latach 2000-2010.

W początkowym okresie procesu kształtowania się międzynarodowych korporacji lokalizacja nowego zakładu, a w szczególności wybór odpowiedniego miejsca produkcji, związana była z krajem pochodzenia konstruktora. W późniejszym okresie rozwoju przedsiębiorstwa lokowały nowe zakłady produkcyjne w krajach, które dysponowały dużym rynkiem zbytu dla wytwarzanych przez nie produktów, a główną przyczyną wyboru lokalizacji nowego zakładu było dążenie do ograniczenia kosztów transportu. Obecnie wybór najkorzystniejszej lokalizacji inwestycji jest bardzo złożonym procesem, integralnym elementem strategii globalizacyjnej każdego przedsiębiorstwa. Na podjecie decyzji o przeniesieniu produkcji lub rozpoczęciu jej w nowym miejscu ma wpływ szereg czynników, m.in. czynniki związane z optymalizacja procesu produkcji, z poszukiwaniem i dopasowywaniem się do nich oraz czynniki polityczne (Merkisz-Guranowska, Merkisz 2007).

Koncerny motoryzacyjne inwestując w krajach Europy Środkowej i Wschodniej kierują się głównie dostępem do dużego rynku zbytu oraz dostępem do zasobów wytwórczych tych krajów. Koncerny te, podejmując strategiczne decyzje inwestowania wybierają region, który jest zgodny z celami inwestycyjnymi korporacji. Następnie dochodzi do negocjacji określonych warunków inwestowania. W Europie Środkowej jako nowe lokalizacje inwestycji nadal rozważa się 4 kraje: Czechy, Polskę, Słowację i Węgry.

Kraje Europy Środkowo-Wschodniej, w tym także Słowacja, posiadają długie tradycje związane z produkcją samochodów. Na terenie dawnej Czechosłowacji swoją działalność już na początku XX wieku prowadziły niewielkie zakłady zlokalizowane w Mladej Bolesław produkujące samochody marki Laurin i Klement. Zakłady te w późniejszych latach weszły w skład koncernu Škoda. Kolejnymi zakładami produkującymi samochody osobowe były zakłady produkujące samochody marki Tatra zlokalizowane w miejscowości Koprivnice, Tarnawskie Automobilowe Zawody (TAZ) z Trnawy, produkujące samochody dostawcze, a w późniejszym okresie również samochody osobowe na licencji Škody, a także Bratysławskie Automobilowe Zawody (BAZ) z Bratysławy, produkujące samochody osobowe na licencji Škody (ryc. 1). W 1989 roku roczna produkcja przemysłu motoryzacyjnego Czechosłowacji wynosiła około 193 tys. szt. samochodów osobowych produkowanych głównie przez koncern Škoda w zakładach w Mladej Bolesław, Kwasiny i Vrchlabi. W 1989 roku koncern Škoda eksportował około 45 tys. szt. samochodów do krajów Europy Zachodniej (Dobosiewicz 1992).

W październiku 1992 r. parlament Czechosłowacji przyjął uchwałę o powstaniu od 1.01.1993 roku suwerennych Czech i Słowacji. Na terenie Słowacji pozostały zakłady TAZ i BAZ, które stały się podwalinami współczesnego słowackiego przemysłu motoryzacyjnego.

Ze względów politycznych, aż do 1989 roku międzynarodowe korporacje, w tym korporacje motoryzacyjne, nie prowadziły działalności inwestycyjnej na terenach dzisiejszej Słowacji. Dopiero po 1989 r. koncerny te zdecydowały się na inwestycję w krajach Europy Środkowej i Wschodniej. Inwestując w tych krajach, w tym także na terytorium dzisiejszej Słowacji, koncerny te dysponowały wieloma atutami konkurencyjnymi, m.in.: atrakcyjnymi produktami, nowymi technologiami, nowoczesnymi systemami informatycznymi, dostępem do znacznych zasobów kapitału, silnym marketingiem, wsparciem swoich sieci korporacyjnych i in. (Kamiński 2005). 


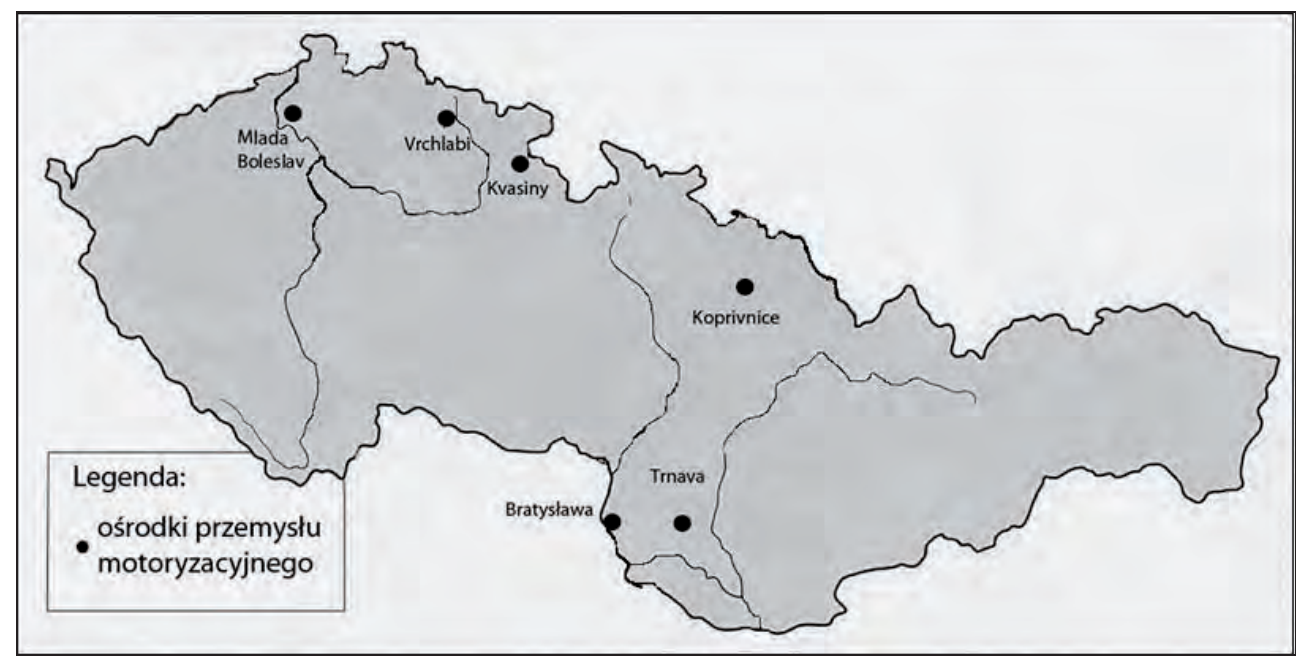

Ryc. 1. Struktura przestrzenna zakładów produkujących samochody osobowe w Czechosłowacji w $1990 \mathrm{r}$.

Źródło: opracowanie własne

W 1991 r. koncern Volkswagen za kwotę 416 mln USD przejął 31\% udziałów koncernu Škoda (zakładów zlokalizowanych obecnie na terenie Czech), zaś w 1995 r. za kwotę $520 \mathrm{mln}$. USD zwiększył swój udział do około 70\%, a do roku 2000 stał się jedynym właścicielem koncernu (Legard 2005). Równocześnie z przejęciem koncernu Škoda Volkswagen podjął starania dotyczące zakupu akcji Bratysławskich Zakładów Samochodowych (BAZ), konkurując z koncernami GM/Opel i Renault. Po zakupie zakładów BAZ koncern Volkswagen w krótkim czasie rozpoczął na terenie tego zakładu znaczne inwestycje, instalując m.in. zupełnie nowe linie technologiczne. Łącznie w zakłady w Bratysławie zainwestował około 1,5 mld USD (Uhlrik 2007; Jakubiak, Kolesar, Izvorski, Kurekova 2008). W późniejszych latach został on uznany za jeden z najnowocześniejszych zakładów koncernu Volkswagen.

Rozwój przemysłu samochodów osobowych w Słowacji nastąpił znacznie później niż w większości krajów Europy czy świata. Poza wymienioną inwestycją koncernu Volkswagen na terenie kraju nie było zakładów produkujących samochody osobowe na dużą skalę, produkcja słowackiego przemysłu motoryzacyjnego nie przekraczała 40 tys. sztuk. Dopiero od roku 1997 nastąpił dynamiczny wzrost produkcji samochodów osobowych.

Przemysł motoryzacyjny w Słowacji koncentruje się w trzech regionach kraju (ryc. 2). Najwięcej zakładów branży motoryzacyjnej zlokalizowanych jest w zachodniej części, gdzie znajdują się fabryki największych producentów samochodów osobowych - Volkswagena w Bratysławie i PSA w Trnawie. Drugim regionem, w którym zlokalizowano wiele zakładów branży motoryzacyjnej, jest północna i centralna część kraju, a największym zakładem tam zlokalizowanym jest KIA Motors w Žilinie. Trzecim regionem, w którym dominuje przemysł motoryzacyjny, jest region położony na wschodzie kraju w okolicach miast Koszyce i Kochenec, gdzie produkuje się układy napędowe w zakładach Ford Gertrag i Molex.

W latach 1997-2008 produkcja samochodów osobowych wskazywała ciągłą tendencje wzrostową, zwiększyła się z około 41852 sztuk w roku 1997 do 576776 szt. w 2008 r., 


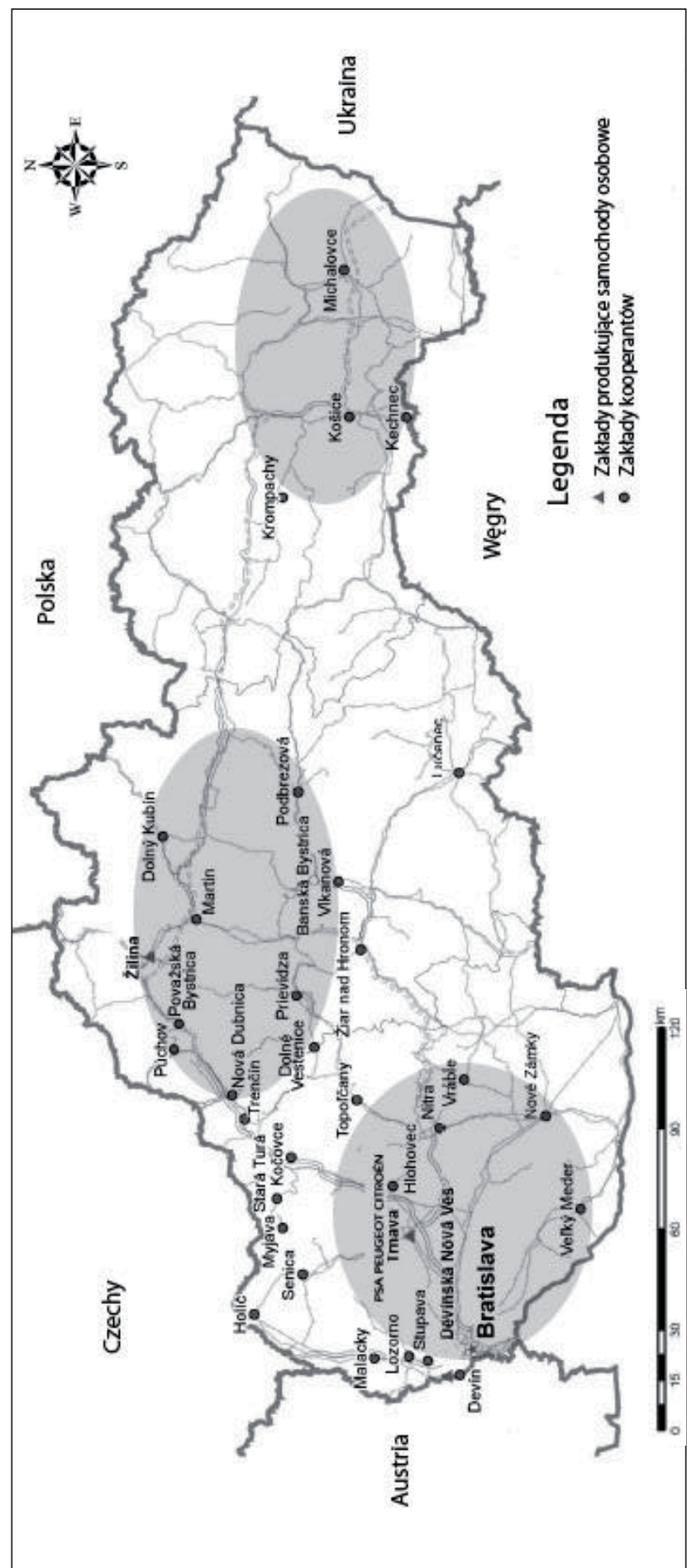

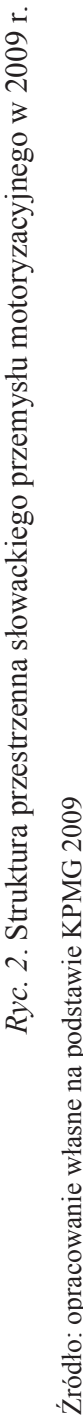


co oznacza ponadtrzynastokrotne zwiększenie produkcji. W ostatnim roku na skutek zmniejszenia popytu na produkowane samochody, głownie w krajach Europy Zachodniej, produkcja zmniejszyła się o 115436 szt. z 576776 w 2008 r. do 461340 szt. w 2009 r., tj. zmniejszyła się o $20 \%$ (ryc. 3 ).

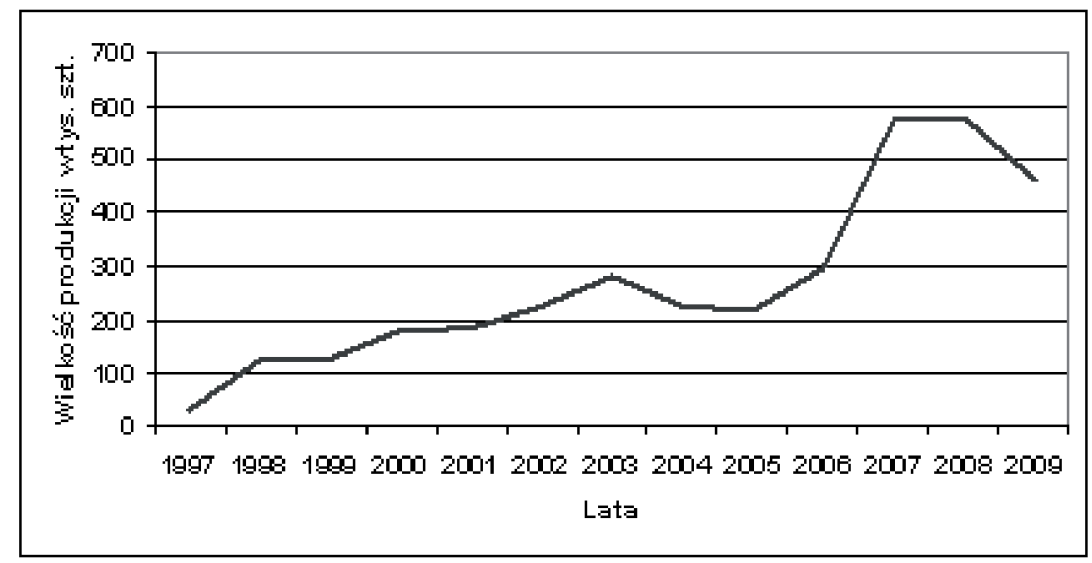

Ryc. 3. Produkcja samochodów osobowych na Słowacji w latach 1997-2009

Źródło: opracowanie własne na podstawie raportów OICA za lata 1997-2009

Biorąc pod uwagę wielkość produkcji w latach 1997-2009 można wyróżnić dwa okresy wzrostu przemysłu samochodowego na Słowacji.

Pierwszy okres obejmuje lata 1997-2003 i charakteryzuje się niższym niż w latach późniejszych wzrostem produkcji samochodów osobowych oraz wysoką wartością wskaźnika dynamiki produkcji. W latach 1997-2003 poziom produkcji wzrósł o 239308 szt. z 41852 szt. w 1997 roku do 281160 w 2003 r. tj. wzrósł sześciokrotnie.

Drugi okres obejmujący lata 2005-2008 cechuje znaczne zwiększenie produkcji, lecz niższa wartość wskaźnika dynamiki, produkcja wzrosła o 358427 sz. z 218349 szt. w 2005 r. do 576776 szt. w 2008 r., tj. do 263\%. Dynamiczny wzrost liczby produkowanych samochodów związany jest z osiagnięciem przez zakłady PSA i KIA pełnej zdolności wytwórczej na poziomie około 250-300 tys. szt.

Dzięki transformacji słowackiej gospodarki terytorium kraju stało się bardzo atrakcyjnym obszarem lokalizacji nowych zakładów produkujących samochody osobowe.

Należy zaznaczyć, iż po roku 2000 wszystkie znaczące inwestycje związane z produkcją samochodów osobowych w Europie Środkowo-Wschodniej lokowane były na terenie Czech oraz Słowacji. W 2002 r. koncerny Toyota, Peugeot i Citroën (TPCA) zdecydowały o budowie nowego zakładu w Kolinie w Czechach, zaś w 2006 r. koncern Hyundai postanowił wybudować nowy zakład w Nosovicach w Czechach. W 2003 r. na terenie Słowacji na znaczne inwestycje związane z budową nowych zakładów produkujących samochody osobowe zdecydował się koncern PSA (Peugeot, Citroën), a w 2004 r. koncern KIA, którego łączna suma inwestycji na Słowacji waha się pomiędzy $700 \mathrm{mln}-1 \mathrm{mld}$. USD.

Dynamiczny wzrost produkcji samochodów osobowych na Słowacji w latach 19922009 spowodowany był w głównej mierze napływem strumieni bezpośrednich inwestycji zagranicznych (BIZ) międzynarodowych koncernów motoryzacyjnych. Koncerny te znacz- 
nie zmodernizowały istniejące zakłady, np. Volkswagen w Bratysławie, a także wybudowały nowe zakłady KIA i PSA.

Światowe korporacje, w tym korporacje branży motoryzacyjnej, szukając najlepszej lokalizacji dla nowego zakładu biorą pod uwagę wiele czynników i każdy z nich analizują w odniesieniu do kilku krajów wybranego regionu. Decyzje koncernów PSA i KIA z lat 2003 i 2004, lokalizujące nowe zakłady na terenie Słowacji, dowodzą, iż to Słowacja posiada najbardziej korzystne warunki do powstawania nowych impulsów rozwojowych, przyciągając na swój teren nowe formy działalności gospodarczej, w głównej mierze poprzez napływ BIZ.

We wszystkich fazach decyzjom korporacji o podjęciu nowej działalności inwestycyjnej towarzyszą działania rządów oraz władz lokalnych, aby to właśnie ich teren wybrano pod inwestycję. Świadczy to o tym, iż to korporacje mają możliwość wpływania na przestrzeń społeczno-gospodarczą, która dostosowuje się do ich preferencji lokalizacyjnych. Istotną rolę w procesie rywalizacji poszczególnych regionów jest atrakcyjność inwestycyjna, na którą składają się:

- czynniki rynkowe - wielkość rynku, przyrost populacji, tempo wzrostu gospodarczego, bliskość i dostęp do rynków eksportowych;

- czynniki kosztowe - koszty pracy, wydajność pracy, dostępność surowców, zaplecze kooperacyjne, jakość infrastruktury, możliwość transferu zysków,

- klimat inwestycyjny - stabilność polityczna, stabilność makroekonomiczna, system podatkowy, system prawny, zachęty dla inwestorów (Wieloński 2005; Gontarz, Remusiewicz 2003).

Kształtowanie atrakcyjności inwestycyjnej Słowacji, a także budowanie jej przewagi inwestycyjnej nad pozostałymi krajami dokonywało się poprzez odpowiednią politykę mikroi makroekonomiczną, a także dostępność infrastruktury. Sytuacja ekonomiczna Słowacji na tle innych państw regionu była bardziej konkurencyjna (tab. 1). Zmniejszający się deficyt finansów publicznych państwa, wzrastający PKB stwarzały dogodne warunki dla napływu BIZ.

Położenie geograficzne Słowacji w centralnej części Europy jest jej istotnym walorem lokalizacyjnym ze względu na dużą liczbę i bliskość firm branży motoryzacyjnej. Przynależność Słowacji do międzynarodowych organizacji gospodarczych, w tym do Unii Europejskiej (UE), stwarza możliwość eksportu produktów wytwarzanych na jej terytorium na wspólny rynek zbytu liczący około 350 mln konsumentów. Bliskość innych zakładów produkujących samochody osobowe znacznie zwiększa konkurencyjność regionu, ponieważ całe terytorium Słowacji znajduje się w obszarze potencjalnej współpracy pomiędzy tymi zakładami i znajduje się także w obszarze możliwych dostaw. Poza dużą liczbą zakładów branży motoryzacyjnej Słowacja posiada także rozbudowany system autostrad i dróg krajowych. Obecnie kraj przecinają autostrady D2 relacji północ-południe z Brodski przez Malacky do Bratysławy oraz D1 relacji wschód-zachód z Bratysławy przez Trnawę po Žilinę, co znacznie poprawia efektywność transportu.

Ważnym czynnikiem lokalizacyjnym podnoszącym konkurencyjność Słowacji jest dostęp do wykwalifikowanej siły roboczej. Słowackie społeczeństwo odznacza się stosunkowo wysokim odsetkiem ludności posiadającej wykształcenie średnie na poziomie ok. 87\% (2005). Wskaźnik ten w Polsce kształtuje się na poziomie 84\%, na Węgrzech wynosi 75\%, a w Czechach $89 \%$. 
Tab. 1. Sytuacja ekonomiczna krajów Europy Środkowej w latach 2002-2004

\begin{tabular}{|l|r|r|r|r|r|r|r|r|r|r|r|r|}
\hline & \multicolumn{3}{|c|}{ Słowacja } & \multicolumn{3}{c|}{ Węgry } & \multicolumn{3}{c|}{ Czechy } & \multicolumn{3}{c|}{ Polska } \\
\hline Lata & 2002 & 2003 & 2004 & 2002 & 2003 & 2004 & 2002 & 2003 & 2004 & 2002 & 2003 & 2004 \\
\hline Populacja w mln &. & 5,3 &. &. & 10,1 &. &. & 10,2 &. &. & 38,1 &. \\
\hline $\begin{array}{l}\text { Wskaźnik inflacji } \\
\text { (rok do roku) }\end{array}$ & 3,3 & 7,3 & 9,5 & 5,5 & 4,4 & 6,8 & 1,9 & 0,1 & 2,8 & 1,9 & 0,7 & 4,4 \\
\hline Wskaźnik PKB & 4,4 & 4,2 & 5,5 & 3,8 & 3,4 & 5,2 & 1,9 & 3,6 & 4,6 & 1,4 & 3,7 & 5,3 \\
\hline Bezrobocie & 17,5 & 15,3 & 14,3 & 5,8 & 5,9 & 6,0 & 9,2 & 9,9 & 9,8 & 19,9 & 19,6 & 19,0 \\
\hline $\begin{array}{l}\text { Dług publiczny } \\
\text { jako \% PKB }\end{array}$ & 50,0 & 48,2 & 47,0 & 60,3 & 61,4 & 65,1 & 32,8 & 34,7 & 34,5 & 55 & 55,3 & 55,3 \\
\hline
\end{tabular}

Źródło: opracowanie własne na podstawie: Globar Finance Magazinehttp://www.gfmag.com/tools/globaldatabase /economic-data, www.worldwide-tax.com, Raportu OECD Economic Outlook 87 database, June 2010, OECD Factobook 2009: Economic, Enviromental and Social Statistics, International Monetarny Found,http://www. imf.org/external/pubs/ft/weo/2010/01/weodata,Eurostat:http://epp.eurostat.ec.europa.eu/portal/page/portal/government_finance_statistics/data/main_tables, CIA Raport https://www.cia.gov/library /publications/ the-world-factbook/rankorder/2186rank.html, The Economist http://www. economist. com/node $/ 16397110$ ? story_id=16397110

Niskie koszty pracy są jednym z najważniejszych powodów przenoszenia bądź lokowania nowych zakładów. Znaczne zróżnicowanie kosztów pracy pomiędzy krajami Europy Środkowo-Wschodniej w porównaniu z krajami Europy Zachodniej podnosi konkurencyjność tych krajów. Dla przykładu koszt roboczogodziny w Niemczech wynosił w 2004 r. 27,1 euro, natomiast w krajach Europy Środkowej (Polska, Czechy, Słowacja, Węgry) od 3 do 4,8 euro (tab. 2). Różnicę w kosztach pracy pomiędzy Słowacją a innymi krajami Europy Środkowej nie są tak znaczne jak w przypadku Niemiec. Wśród krajów Europy Środkowej to właśnie Słowacja wyróżniała się najniższymi kosztami pracy, wieloma przywilejami dla rozwoju działalności gospodarczej, a także dostępnością znacznych zasobów wykwalifikowanej kadry (tab. 3, ryc. 4).

Tab. 2. Zmiany wskaźnika kosztów pracy w wybranych krajach Europy Środkowej w latach 2004-2009

\begin{tabular}{|l|c|c|c|}
\hline $\begin{array}{c}\text { Kraj / Wynagrodzenie } \\
\text { za godzinę pracy [euro] }\end{array}$ & 2004 & 2009 & $\begin{array}{c}\text { Wskaźnik dynamiki } \\
\text { w \% }\end{array}$ \\
\hline Czechy & 4,8 & 6,4 & 133 \\
\hline Niemcy & 27,1 & 29,8 & 110 \\
\hline Polska & 4,1 & 5,3 & 129 \\
\hline Słowacja & 3,0 & 4,1 & 137 \\
\hline Węgry & 4,8 & 6,4 & 133 \\
\hline UE & 20,5 & 23,4 & 114 \\
\hline
\end{tabular}




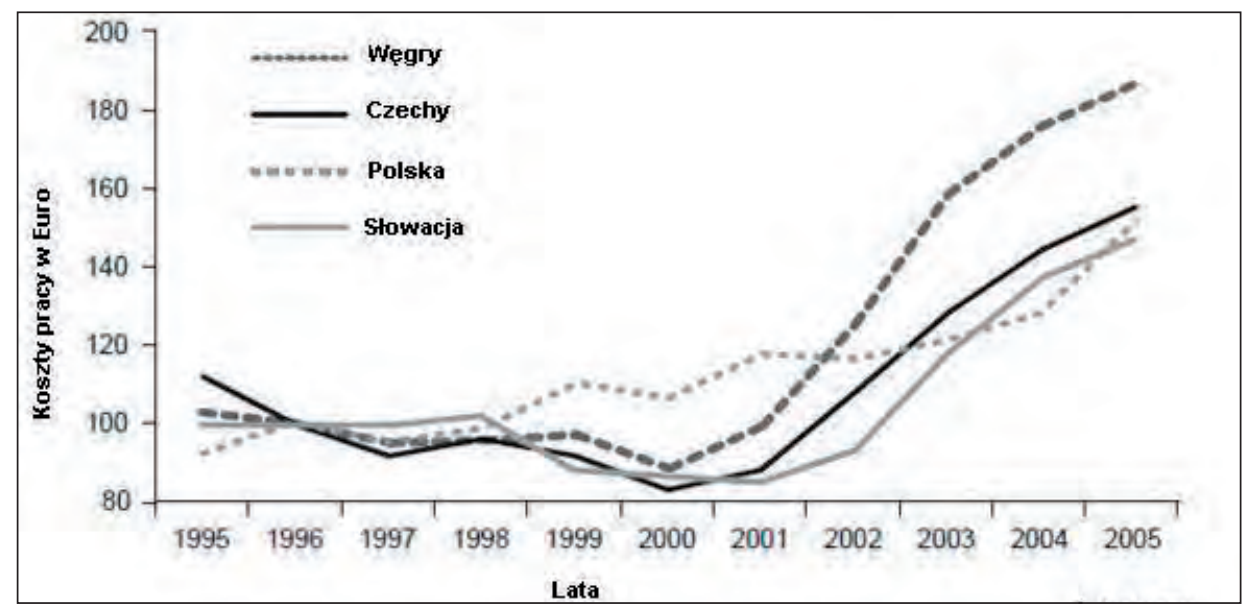

Ryc. 4. Zmiany kosztów pracy w wybranych krajach Europy Środkowej w latach 1995-2005 $(1996=100)$

Źródło: Jakubiak, Kolesar, Izvorski, Kurekova 2008

Tab. 3. Koszty pracy w wybranych krajach Europy Środkowej w latach 2004 i 2006

\begin{tabular}{|c|c|c|c|c|c|c|c|c|}
\hline & \multicolumn{2}{|c|}{ Czechy } & \multicolumn{2}{|c|}{ Węgry } & \multicolumn{2}{|c|}{ Polska } & \multicolumn{2}{|c|}{ Słowacja } \\
\hline & \multicolumn{8}{|c|}{ Lata } \\
\hline & 2004 & 2006 & 2004 & 2006 & 2004 & 2006 & 2004 & 2006 \\
\hline $\begin{array}{l}\text { Minimalne wynagrodzenie } \\
\text { w Euro }\end{array}$ & 212 & 280 & 209 & 230 & 180 & 223 & 152 & 181 \\
\hline $\begin{array}{l}\text { Średni koszt roboczogodziny } \\
\text { w Euro }\end{array}$ & 5,78 & 6,56 & 5,72 & 6,57 & 4,92 & 5,78 & 4,23 & 4,56 \\
\hline $\begin{array}{l}\text { Socjalne (społeczne) } \\
\text { obciążenia pracy (koszty } \\
\text { pracodawcy) w \% pensji }\end{array}$ & 47,5 & & 47 & & 48 & & 41,1 & \\
\hline
\end{tabular}

Źródło: opracowanie własne na podstawie Eurostat; Allen \& Overy 2005; KPMG 2006

Nie bez znaczenia dla wyboru lokalizacji przedsiębiorstw jest również postawa władz szczebla państwowego i lokalnego. Na poziomie krajowym władze spełniają funkcje regulacyjne w zakresie prawno-podatkowym, natomiast na szczeblu lokalnym pełnią w głównej mierze funkcje operacyjno-zarządcze, tj. tworzą dobry klimat dla nowych inwestycji.

Od połowy lat 90 . XX w. słowacki rząd podejmował działania mające na celu rozwój branży motoryzacyjnej, a przyjęty „Program dla rozwoju przemysłu motoryzacyjnego w Słowacji” precyzyjnie określił ogólną strategię rozwoju tej branży. Rządowy dekret nr 192/1998 przyznający koncernowi Volkswagen zwolnienie podatkowe do kwoty 31,2 mln euro, przyczynił się do napływu na Słowację wielu zagranicznych kooperantów branży motoryzacyjnej, m.in. Lear Corporation, i odegrał pozytywną rolę w kształtowaniu pozytywnego klimatu inwestycyjnego, w znaczący sposób wpływając na dalsze decyzje inwestorów 
w następnych latach. Kolejne rządy starały się utrzymać wyznaczoną wcześniej drogę rozwoju tej branży.

Kolejnym atutem podnoszącym stopień konkurencyjności Słowacji względem innych krajów Europy Środkowej była przeprowadzona w 2004 r. reforma systemu podatkowego. Wprowadzając reformę podatkową słowacki rząd częściowo obniżył podatki, wyeliminował 21 typów podatków pośrednich i stworzył nowy, przejrzysty i prosty system podatkowy ukierunkowany na motywowanie działalności gospodarczej (tab. 4).

Tab. 4. Wysokość podatków w krajach Europy Środkowej

\begin{tabular}{|l|c|c|c|c|}
\hline Kraj / Opodatkowanie w \% & Czechy & Węgry & Polska & Słowacja \\
\hline Podatek CIT (ustawowy) & 24,0 & 16,0 & 19,0 & 19,0 \\
\hline Podatek CIT (rzeczywisty) & 17,1 & 14,0 & 17,5 & 16,8 \\
\hline Podatek VAT (stawka podstawowa) & 19,0 & 20,0 & 22,0 & 19,0 \\
\hline Podatek dochodowy od ludności & $15-32$ & $18-38$ & $19-40$ & 19,0 \\
\hline
\end{tabular}

Źródło: Allen \& Overy 2005

W latach 90. XX w. w celu pozyskania strumieni bezpośrednich inwestycji zagranicznych wszystkie kraje Europy Środkowej podejmowały inicjatywy zmierzające do stworzenia ulg i zwolnień podatkowych dla przedsiębiorstw inwestujących na ich obszarze. Po wstąpieniu do UE kraje te musiały znacznie ograniczyć pomoc publiczną dla nowych inwestycji. W myśl obowiązujących przepisów UE pomoc rządowa dla przedsiębiorstw jest prawnie zakazana, ponieważ powoduje zaburzenie konkurencji. Zwolnienia podatkowe i subwencje mogą zostać przyznane jedynie w przypadku realizacji dużych inwestycji, które znacząco przyczyniają się do regionalnego rozwoju i jednocześnie nawiązują do polityki spójności UE. W takim przypadku całkowita wartość pomocy rządowej nie może przekroczyć 15\% całkowitej wartości inwestycji (EC 1997). W rzeczywistości bardzo trudno jednak obliczyć łączną wartość pomocy udzielonej inwestorowi (Carlton, 2003). Zakwalifikowanie danej inwestycji jako inwestycji dobra publicznego pozwala na zwiększenie limitu pomocy publicznej. Wstąpienie krajów Europy Środkowej do UE nie zahamowało jednak konkurencji tych krajów w udzielaniu przez nie pomocy publicznej inwestorom.

W wielu przypadkach w walce konkurencyjnej o przyciagnięcie zagranicznych inwestycji wiele krajów używa dodatkowych argumentów. W przypadku negocjacji słowackiego rządu z koncernem motoryzacyjnym KIA poza ustawowym maksimum pomocy publicznej w wysokości 15\% dodatkowo zaoferowano szybkie wybudowane autostrady do Žiliny, modernizację portu lotniczego Dolny Hricov oraz terminala kolejowego oraz budowę domów mieszkalnych dla kadry zarządzającej niedaleko Žiliny i Bratysławy, a także utworzenie szkół z językiem angielskim dla dzieci pracowników.

Stwierdzić należy, iż suma całkowitej pomocy publicznej Słowacji dla pozyskania nowej inwestycji koncernu KIA w Trnawie znacznie przewyższała 15\% dopuszczalnej przez UE wartości inwestycji. Kwota 15\% wartości inwestycji dotyczyła bowiem tylko bezpośredniej pomocy państwa dla inwestora. Obietnica dokonania znacznych nakładów finansowych w rozbudowę lokalnej infrastruktury pomogła zrealizować tę inwestycję bez naruszania ograniczeń Unii Europejskiej dotyczącej pomocy publicznej państwa dla przedsiębiorstw. 
Słowacki przemysł motoryzacyjny w ostatniej dekadzie stał się najważniejszym sektorem krajowej gospodarki - wytwarzał w 2009 r. około 33\% PKB i zatrudniał około 87 tys. pracowników, co stanowi około $10 \%$ ogółu zatrudnionych.

Napływ bezpośrednich inwestycji zagranicznych na teren Słowacji umożliwiony po przemianach polityczno-gospodarczych pozwolił na podniesienie jakości produkowanych wyrobów oraz znaczne rozwinięcie produkcji nowych marek samochodów. Współczesny słowacki przemysł samochodów osobowych to nie tylko fabryki produkujące samochody osobowe, ale także nowe przedsiębiorstwa, które powstały w okolicach tych fabryk. Zadziałał tu mechanizm naśladownictwa, wokół dużych zakładów produkujących samochody występują znaczne skupienia innych firm branży motoryzacyjnej współpracujących z fabrykami samochodów, jak producenci podzespołów, części zamiennych, chłodnic, amortyzatorów i in. (Faurencia, Continental, PSA Suppilers, Johnson Controls, Lear Corporation, Magna, Delphi Automotive Systems, Summimoto).

Należy więc podkreślić, iż dzięki napływowi na teren Słowacji bezpośrednich inwestycji zagranicznych nastąpiła dywersyfikacja rynku. Ważnym aspektem dynamizującym rozwój przemysłu motoryzacyjnego był fakt przeprowadzenia szeregu reform, w tym m.in. reformy podatkowej. Przystapienie w 2004 r. Słowacji do UE sprawiło, iż kraj ten uzyskał dostęp do dużego rynku zbytu (Unii Europejskiej). Akcesja przyczyniła się także do zwiększenia stabilności ekonomicznej i politycznej państwa. Reforma podatkowa obniżająca i znacznie upraszczająca system podatkowy umożliwiła napływ kolejnej fali BIZ i podniosła konkurencyjność całej gospodarki. Znaczne zasoby siły roboczej, a także najniższe wśród krajów Europy Środkowej koszty pracy odegrały dużą rolę w pozyskaniu nowych inwestycji.

Podsumowując, należy stwierdzić, iż największe inwestycje branży motoryzacyjnej zlokalizowane na terytorium Słowacji determinowane były znaczną pomocą publiczną państwa bezpośrednią i pośrednią. Pierwszą inwestycję branży motoryzacyjnej pozyskano dzięki obietnicy zwolnienia przedsiębiorstwa z części podatku dochodowego. Inwestycje z lat 2003 i 2004 pozyskano dzięki zaoferowaniu inwestorowi maksymalnej możliwej w ramach członkostwa w UE pomocy państwa oraz poprzez udzielenie pomocy pośredniej, m.in. $\mathrm{w}$ formie deklaracji o rozbudowie infrastruktury $\mathrm{i}$ in. W ostatnich 20 latach słowacki przemysł motoryzacyjny przyjął znaczne strumienie BIZ i stał się dzięki temu częścią gospodarki globalnej.

\section{Literatura}

Allen \& Overy, 2005, "Foreign Direct Investment in Central and Eastern Europe" (Available at: http:// www. allenovery. com/ AOWeb/ binaries/ 27644.pdf)

Charlton A., 2003, "Incentive Bidding for Mobile Investment: Economic Consequences and Potential Responses.” OECD Development Center, Working Paper No. 203, January. (Available at: http:// www.oecd.org/dataoecd/39/63/2492289.pdf.)

Dobosiwicz Z., 1992, Foreign Investment in Europe, London: Routledge, s. 74.

Gontarz J., Remisiewicz M., 2003, Potrzeba inwestycji, Businessman, 1, s. 25-29.

Jakubiak M., Kolesar P., Izvorski I., Kurekova L., 2008, The automotive industry in the Slovak Republic: Recent developments and impact on growth, Working paper, no. 29, The International Bank for Reconstruction and Development / The World Bank on behalf of the Commission on Growth and Development, Washington, s. 9-41.

Kamiński A., 2005, Europa Środkowo-Wschodnia w działalności koncernów międzynarodowych: na przykladzie koncernów motoryzacyjnych, Wyd. Mater, Szczecin. 
KPMG, 2009, “Automotive Momentum: Slovakia - The Automotive Powerhouse of Central Europe?”. KPMG, 2006, "Automotive Momentum: Slovakia - The Automotive Powerhouse of Central Europe?". Kukliński A., red., 2001, Gospodarka oparta na wiedzy. Wyzwanie dla Polski XXI wieku, Warszawa. Ledgard J., 2005, "Skoda Leaps to Market," Strategy + business 40, s. 7. (Available at: http://www. strategy-business.com/ media/ file/ sb40_05306.pdf).

Merkisz-Guranowska A., Merkisz J., 2007, Wybrane aspekty globalizacji w przemyśle motoryzacyjnym, Zeszyty Naukowe Politechniki Poznańskiej. Budowa Maszyn i Zarządzanie Produkcją, Wydawnictwo Politechniki Poznańskiej, Poznań, s. 99-100.

OICA Raports - production statistics by country and type - years 1997-2009.

Uhrik J., 2007, Interview president of the Automotive Industry Association of the Slovak Republic (ZAP SR) and former CEO of Volkswagen Slovakia, 04 March.

Wieloński A., 2005, Geografia przemystu, Wydawnictwo Uniwersytetu Warszawskiego, Warszawa.

Wierzbicki A.P., 1995, Perspektywy cywilizacji światowej XXI wieku a przemiany w Polsce, [w:] Świat przyszłości a Polska. Komitet Prognoz „Polska w XXI wieku”, Warszawa.

Zioło Z., 2001, Informatyzacja przestrzeni gospodarczej jako wyznacznik konkurencyjności regionu, [w:] Konkurencyjność miast i regionów a przedsiębiorczość i przemiany strukturalne, red. A. Klasik, Prace Naukowe AE w Katowicach, Katowice, s. 37-57.

Zioło Z., 2003, Ksztaltowanie się przedsiębiorstw przemystowych w procesie globalizacji, [w:] Przemyst w procesie globalizacji, red. Z. Zioło, T. Rachwał, Prace Komisji Geografii Przemysłu PTG, nr 6, Wydawnictwo Naukowe AP, Kraków, s. 9-20.

Zioło Z., 2004, Ksztaltowanie się firm informatycznych jako nowych elementów struktury przestrzennej przemystu, [w:] Przemiany struktur przemystowych, red. Z. Zioło, T. Rachwał, Prace Komisji Geografii Przemysłu PTG, nr 7, Wydawnictwo Naukowe AP, Kraków, s. 97-106.

Zioło Z., 2006, Zróżnicowanie światowej przestrzeni przemystowej w świetle koncentracji siedzib zarzqdów wiodacych korporacji, [w:] Międzynarodowe uwarunkowania rozwoju przemyshu, red. Z. Zioło, T. Rachwał, Prace Komisji Geografii Przemysłu PTG, nr 8, Wydawnictwo Naukowe AP, Kraków, s. 9-26.

Zioło Z., 2009, Procesy ksztaltowania się światowych korporacji i ich wptyw na otoczenie, [w:] Wpływ procesów globalizacji i integracji europejskiej na transformacje struktur przemystowych, red. Z. Zioło, T. Rachwał, Prace Komisji Geografii Przemysłu PTG, nr 12, Wydawnictwo Naukowe UP, Kraków, s. 11-32.

\section{The process of development of Slovak automotive industry as an expression of the competitiveness of the region}

The spatial systems of different scale try to create the most advantageous conditions for attracting new forms of economic activity to the particular areas by increasing their attractiveness of the new locations for the economic activities.

With reference to the presented premises the process of forming Slovak automotive industry is presented. The paper presents the essential factors that caused competitive advantage of Slovakia in comparison to other countries of Central Europe, determining increased streams of direct foreign investments that resulted in, among others, dynamic development of Slovak automotive industry.

Mgr Piotr Lizak

Uniwersytet Pedagogiczny, Kraków

Instytut Geografii

Zakład Przedsiębiorczości i Gospodarki Przestrzennej

e-mail: lizak.piotr@wp.pl 